FONSECA, Lorena; COUTO, Felipe Fróes. Judicialização da Política e ativismo judicial: uma diferenciação necessária. Revista Eletrônica Direito e Política, Programa de Pós-Graduação Stricto Sensu em Ciência Jurídica da UNIVALI, Itajaí, v.13, n.2, 20 quadrimestre de 2018. Disponível em: www.univali.br/direitoepolitica - ISSN 1980-7791

\title{
JUDICIALIZAÇÃO DA POLÍTICA E ATIVISMO JUDICIAL: UMA DIFERENCIAÇÃO NECESSÁRIA
}

\author{
JUDICIALIZATION OF POLITICS AND JUDICIAL ACTIVISM: A NECESSARY \\ DIFFERENTIATION
}

\section{Lorena Fonseca ${ }^{1}$ \\ Felipe Fróes Couto²}

\begin{abstract}
SUMÁRIO: Introdução; 1 Diferenças conceituais entre Ativismo Judicial e Judicialização da Política; 2 As origens da Judicialização Política e Social; 2.1 Pósguerra e o constitucionalismo dirigente; 2.2 Aumento da litigiosidade e das demandas por justiça; 3 As origens do Ativismo Judicial; 3.1 Judicialização e Ativismo em Antoine Garapon; 3.2 A experiência norte-americana de Ativismo Judicial; 3.3 A experiência alemã de Ativismo Judicial; Considerações Finais; Referência das fontes citadas.
\end{abstract}

\section{RESUMO}

O judiciário vem ganhando cada vez mais projeção por transcender sua órbita de atuação, chegando até a esfera política, antes típica dos poderes legislativo e executivo. Tal atuação pode ser compreendida sob um duplo viés: o da judicialização da política e do ativismo judicial. Este trabalho busca diferenciar conceitualmente tais fenômenos, além de apresentar as origens de ambos. Fazendo uso do método descritivo, elaborou-se a presente pesquisa de natureza qualitativa. Nosso argumento, ao longo do artigo, é que a judicialização é fruto de um contexto social e político em que há transferência para o Judiciário de questões que não são exclusivamente jurídicas e tem como causas o constitucionalismo do segundo pós-guerra, a noção de "constituição dirigente" e o aumento das demandas por justiça. Por outro lado, o ativismo trata de ato de vontade, de postura interpretativa. Para encontrar suas origens, reportamo-nos à "Teoria Pura do Direito" de Kelsen, ao "O guardador de promessas" de Garapon, além do Judicial review dos EUA e da Jurisprudência de Valores da Alemanha.

Palavras-chave: Ativismo judicial; Judicialização da política; Poder judiciário.

\section{ABSTRACT}

The judiciary has been gaining more and more projection for transcending its orbit of action, reaching the political sphere, formerly typical of the legislative and executive powers. Such action can be understood under a double bias: the judicialization of politics and judicial activism. This work seeks to conceptually differentiate such phenomena, in addition to presenting the origins of both. Making use of the descriptive method, the present qualitative research was elaborated. Our argument, throughout

\footnotetext{
${ }^{1}$ Pesquisadora-Bolsista da Coordenação de Aperfeiçoamento de Pessoal de Nível Superior (CAPES), Belo Horizonte/MG - Brasil. Mestranda em Direito pela Universidade Federal de Minas Gerais (UFMG). E-mail: lorena.fonseca@outlook.com

2 Professor de Educação Superior da Universidade Estadual de Montes Claros (UNIMONTES). Montes Claros/MG - Brasil. Doutorando em Estudos Organizacionais e Sociedade pela Universidade Federal de Minas Gerais (UFMG). E-mail: felipe.couto@unimontes.br
} 
FONSECA, Lorena; COUTO, Felipe Fróes. Judicialização da Política e ativismo judicial: uma diferenciação necessária. Revista Eletrônica Direito e Política, Programa de Pós-Graduação Stricto Sensu em Ciência Jurídica da UNIVALI, Itajaí, v.13, n.2, 20 quadrimestre de 2018. Disponível em: www.univali.br/direitoepolitica - ISSN 1980-7791

the article, is that the judicialization is the result of a social and political context in which there is a transfer of issues that are not exclusively legal to the Judiciary and which causes are the constitutionalism of the second post-war period, the notion of " Constitution as a Driving Force" and increasing demands for justice. On the other hand, activism deals with an act of will, of an interpretative stance. To find its origins, we refer to Kelsen's "Pure Theory of Law, " Garapon's "Keeper of Promises," as well as the US Judicial Review and the case law of Germany.

Keywords: Judicial activism; Judicialization of politics; Judiciary.

\section{INTRODUÇÃO}

A atuação do poder judiciário em decisões de questões de largo alcance político, seja envolvendo escolhas morais em temas controversos, seja versando sobre implementação de políticas públicas, gera ora aplausos, ora críticas. É comum a produção de trabalhos acadêmicos e divulgação de notícias a respeito de uma dita "judicialização da política" ou do intenso "ativismo judicial". Ocorre que todos os acontecimentos são postos em um mesmo arcabouço, muitas vezes, sem precisão conceitual alguma.

Escrevemos este artigo diante da necessidade percebida de uma maior diferenciação entre "judicialização da política" e "ativismo judicial". O objetivo é distinguir tais fenômenos e apresentar suas origens não-coincidentes. Utilizaremos como metodologia de pesquisa o método descritivo, objetivando descrever e compreender os fatos/teorias afetos à temática ${ }^{3}$. A técnica utilizada será a bibliográfica, com uso de pesquisa jurisprudencial, a fim de levantar um melhor entendimento do tema em casos específicos.

Na seção número um apresentaremos as diferenças conceituais entre ativismo judicial e judicialização da política. Primeiro, vamos indicar como esses fenômenos costumam ser considerados e depois iremos demarcar os conceitos de um e de outro, bem como exemplificá-los. Na seção número dois, trataremos das origens da judicialização da política, discorreremos sobre o contexto pós-guerra, o constitucionalismo dirigente, o aumento da litigiosidade e das demandas por justiça. Na seção de número três, iremos discorrer sobre as origens do ativismo judicial. Primeiro, alocando-o no âmbito da Teoria do Direito, através da noção de interpretação jurídica como ato de vontade, de

\footnotetext{
${ }^{3}$ LAKATOS, Eva Maria; MARCONI, Marina de Andrade. Metodologia científica. São Paulo: Atlas, 2000. p. 46. "A função final da atividade científica é se obter a verdade, através da comprovação de hipóteses, observando a realidade e a teoria, que explica então a realidade".
} 
FONSECA, Lorena; COUTO, Felipe Fróes. Judicialização da Política e ativismo judicial: uma diferenciação necessária. Revista Eletrônica Direito e Política, Programa de Pós-Graduação Stricto Sensu em Ciência Jurídica da UNIVALI, Itajaí, v.13, n.2, 20 quadrimestre de 2018. Disponível em: www.univali.br/direitoepolitica - ISSN 1980-7791

acordo com Kelsen. Segundo, apontando como ocorre a transição da judicialização para o ativismo, de acordo com Garapon. Terceiro, fazendo um breve histórico da experiência norte-americana de ativismo judicial para apontar as suas mais variadas formas. Quarto, apresentando como a jurisprudência de valores retomou o protagonismo e a discricionariedade judicial do tribunal constitucional alemão. $\mathrm{Na}$ última seção, apresentaremos as considerações finais que apontam, sobretudo, que o ativismo judicial aparece como um problema criado exclusivamente pelo âmbito jurídico, diferente da judicialização, que está condicionada a acontecimentos externos ao Direito. Além disso, apontamos que o problema do ativismo é de cunho interpretativo, sendo necessário averiguar se a intervenção do judiciário ocorre dentro dos limites constitucionais.

\section{DIFERENÇAS CONCEITUAIS ENTRE ATIVISMO JUDICIAL E JUDICIALIZAÇÃO DA POLÍtTICA}

O judiciário não tem se restringido apenas à solução e pacificação dos conflitos sociais dentro do processo judicial, ele vem ganhando cada vez mais projeção, e isso pode ser visto rotineiramente nos noticiários ${ }^{4}$. Essa postura mais participativa e decisiva em matérias polêmicas pode ser encontrada em vários julgados. Na ADI 3510, por exemplo, foi declarada a constitucionalidade do art. $5^{\circ}$ da Lei de Biossegurança, o que permitiu e disciplinou as pesquisas com células-tronco embrionárias. Essa foi uma questão moralmente e cientificamente relevante que ficou no âmbito do Supremo Tribunal Federal (STF) que decidiu que essas pesquisas não violam o direito à vida.

Um segundo exemplo seria a ADC 12, na qual se declarou a constitucionalidade da Resolução no 7 de 2005 do Conselho Nacional de Justiça, que resultou na vedação do nepotismo no âmbito do Poder Judiciário. Neste caso, aplicou-se a Constituição da República Federativa do Brasil de 1988 (CF/88) a situações não expressamente

${ }^{4}$ A) Vaga de deputado licenciado é de suplente da coligação, decide STF. Disponível em: <http://g1.globo.com/politica/noticia/2011/04/vaga-de-deputado-licenciado-e-de-suplente-da-coligacaodecide-stf.html>. Acesso em 10/02/2015.

B) Aborto de anencéfalos não é mais crime, decide STF. Disponível em: $<$ http://noticias.terra.com.br/brasil/aborto-de-anencefalos-nao-e-mais-crime-decidestf,517bdc840f0da310VgnCLD200000bbcceb0aRCRD.html>. Acesso em: 11/02/2015.

C) Toque de recolher chega ao Paraná - Juíza de Cambará baixa portaria que restringe circulação de crianças e adolescentes à noite. Disponível em: <http://www.gazetadopovo.com.br/vida-ecidadania/toque-de-recolher-chega-ao-parana-bnl0wlikm5zifcqgdf4e0tgzy>. Acesso em: 06/05/ 2015. 
FONSECA, Lorena; COUTO, Felipe Fróes. Judicialização da Política e ativismo judicial: uma diferenciação necessária. Revista Eletrônica Direito e Política, Programa de Pós-Graduação Stricto Sensu em Ciência Jurídica da UNIVALI, Itajaí, v.13, n.2, 20 quadrimestre de 2018. Disponível em: www.univali.br/direitoepolitica - ISSN 1980-7791

contempladas em seu texto e sem manifestação do legislador ordinário. Além disso, alcançou os poderes legislativo e executivo, com a edição da Súmula Vinculante no 13. Ainda que baseada nos princípios da moralidade e da impessoalidade, o STF extraiu uma vedação que não constava em qualquer regra constitucional ou infraconstitucional expressa.

Esses apontamentos, além de exemplificarem a dita expansão do poder judiciário, têm como objetivo levantar os seguintes questionamentos: Qual exemplo trata da judicialização da política? E qual trata de ativismo judicial? Quais as diferenças entre eles? Não são raras as confusões entre os fenômenos, por isso, demarcar-se-á conceitualmente do que exatamente estamos tratando.

A judicialização, chamada por Barroso 5 de "judicialização da vida", é um fenômeno no qual uma série de questões de ampla repercussão no seio político e social vem sendo deliberadas e decididas pelo poder judiciário e não pelo Congresso Nacional ou pelo poder Executivo, como tradicionalmente ocorria.

Já o ativismo judicial, Barroso ${ }^{6}$ conceituou como a participação abrangente e intensa do judiciário, que se manifesta através da aplicação direta da Constituição em situações não expressamente previstas no texto, independente da manifestação do legislador ordinário. Segundo o constitucionalista, há também manifestação de ativismo na imposição de condutas ao poder público em matéria de política pública ou na declaração de inconstitucionalidade de ato normativo emanado do legislador baseados em critérios menos rígidos.

Entretanto, as definições dos fenômenos dadas pelo autor não são pacíficas. Tassinari ensina que "o problema é que os elementos que Barroso elenca como caracterizadores do ativismo, no atual paradigma constitucional, devem ser inerentes a qualquer juiz no exercício de suas atribuições"7. A autora ainda explica que não é novidade que o Juiz deva se mostrar "preocupado com a aplicação imediata da Constituição, com a

\footnotetext{
${ }^{5}$ BARROSO, Luís Roberto. Judicialização, ativismo judicial e legitimidade democrática. [Syn]Thesis, Rio de Janeiro, v. 5, n. 1, p. 23-32, 2012.

${ }^{6}$ BARROSO, Luís Roberto. [Syn]Thesis, p. 23-32.

7 TASSINARI, Clarissa. Ativismo judicial: uma análise da atuação do judiciário nas experiências brasileira e norte-americana. Dissertação (Mestrado em Direito) - Universidade do Vale do Rio dos Sinos. São Leopoldo, 2012, p. 20.
} 
FONSECA, Lorena; COUTO, Felipe Fróes. Judicialização da Política e ativismo judicial: uma diferenciação necessária. Revista Eletrônica Direito e Política, Programa de Pós-Graduação Stricto Sensu em Ciência Jurídica da UNIVALI, Itajaí, v.13, n.2, 20 quadrimestre de 2018. Disponível em: www.univali.br/direitoepolitica - ISSN 1980-7791

realização de um efetivo controle de constitucionalidade e com o cumprimento das finalidades constitucionais"s.

Segundo Tomaz de Oliveira9 ${ }^{9}$, Barroso considera ativismo judicial e judicialização "primos" e "provenientes da mesma família", contudo, as origens dos fenômenos são distintas e os contornos de cada um, ou seja, sua "carga genética" são diferentes e apontam que os fenômenos não são da mesma "família".

Tomaz de Oliveira ${ }^{10}$ então explica que a judicialização possui um aspecto mais sociológico, com origens de natureza política ou social, enquanto o ativismo judicial é um problema ligado à postura interpretativa do Judiciário. Nas palavras do autor:

A judicialização ocorre por fatores que não guardam relação direta com a ação do Poder Judiciário. São fatores contingentes, que se apresentam em razão da adoção de uma determinada política legislativa ou administrativa. Já o ativismo judicial decorre diretamente de um ato de vontade do Poder Judiciário. Como afirma Antonie Garapon, trata-se de um fenômeno que tem origem no desejo do julgador de operar algum tipo de mudança ou conservação de determinadas posições sociais ${ }^{11}$.

Desse modo, quando os magistrados adotam uma postura ativista, eles utilizam de cada oportunidade do seu exercício de poder para ampliar o espectro político. Assim, as decisões políticas não passam por um amplo debate racional, sendo decididas no âmbito judicial no qual o juiz exerce um papel partidário e é influenciado por convicções ideológicas ${ }^{12}$.

Streck ensina que "um juiz ou tribunal pratica ativismo quando decide a partir de argumentos de política, de moral, enfim, quando o direito é substituído pelas

\footnotetext{
8 TASSINARI, Clarissa. Ativismo judicial: uma análise da atuação do judiciário nas experiências brasileira e norte-americana, p. 20.

9 TOMAZ DE OLIVEIRA, Rafael et al. A jurisdição constitucional entre a judicialização e o ativismo: percursos para uma necessária diferenciação. Anais do $\mathbf{X}$ Simpósio Nacional de Direito Constitucional, 2012, p. 271.

10 TOMAZ DE OLIVEIRA, Rafael. Ficha Limpa intensificou a judicialização da política. Revista Consultor Jurídico, 6 de outubro de 2012. Disponível em: <http://www.conjur.com.br/2012-out-06/diario-classeficha-limpa-intensificou-judicializacao-politica>. Acesso em 18/02/2015 às $12 \mathrm{~h}$.

11 TOMAZ DE OLIVEIRA, Rafael. Revista Consultor Jurídico, s.p.

12 TATE, C. Neal; VALLINDER, Torbjörn (Eds.). The global expansion of judicial power. New York: New York University Press, 1995, p. 34.
} 
FONSECA, Lorena; COUTO, Felipe Fróes. Judicialização da Política e ativismo judicial: uma diferenciação necessária. Revista Eletrônica Direito e Política, Programa de Pós-Graduação Stricto Sensu em Ciência Jurídica da UNIVALI, Itajaí, v.13, n.2, 20 quadrimestre de 2018. Disponível em: www.univali.br/direitoepolitica - ISSN 1980-7791

convicções pessoais de cada magistrado"13 e que por outro lado, a judicialização é um "fenômeno que exsurge a partir da relação entre os poderes do Estado (pensemos, aqui, no deslocamento do polo de tensão dos Poderes Executivo e Legislativo em direção da justiça constitucional"14.

Logo, a judicialização da política é um processo social no qual área de atuação dos tribunais é ampliada pelo poder constituinte ou parlamentar, de modo que a vida política, social e econômica é "juridicizada", ou seja, é sujeita à ação judicial. A judicialização não é escolhida, nem promovida pelo juiz, mas é produto da alteração do texto constitucional ou legal que amplia a competência dos órgãos judiciais ${ }^{15}$.

Devido ao exposto, podemos aduzir que a supramencionada ADI 3510 é um exemplo de judicialização, pois uma questão com alto grau de importância para a sociedade, não somente para o campo jurídico, e classicamente exterior à esfera de atuação do poder judiciário, nela foi decidida. Apesar dos contornos morais e científicos, a decisão foi deslocada para o judiciário que discutiu sobre estatuto jurídico do embrião, "verdades científicas" sobre início da vida e sobre pesquisas biológicas a respeito da utilização de células-tronco embrionárias obtidas através de fertilização in vitro. Nesse caso, o poder de decisão foi transferido para o Tribunal, não por causa de um ato volitivo dele, mas devido à expansão da sociedade e crise da democracia que levam questões a serem deslindadas pelo Judiciário.

Por outro lado, o segundo exemplo, a ADC 12, pode ser enquadrado como caso de ativismo judicial, pois é fruto de postura interpretativa do tribunal que, na sua atuação proativa, criou uma vedação, com o desejo de acelerar a mudança. Contudo, não houve um debate constitucionalmente constituído. O problema aqui é interpretativo e o que se questiona são os limites constitucionais da decisão, já que não havia regra constitucional ou infraconstitucional expressa que vedasse o nepotismo nos âmbitos do judiciário, legislativo e executivo.

13 STRECK, Lenio Luiz. Verdade e consenso. Constituição hermenêutica e teorias discursivas. 4. ed. São Paulo: Saraiva, 2011, p. 589, nota de rodapé 123.

${ }^{14}$ STRECK, Lenio Luiz. Verdade e consenso, p. 589, nota de rodapé 123.

15 LEITE, Roberto Basilone. Déficit político do poder judiciário brasileiro: A falta de efetividade no desempenho de suas funções institucionais e o ativismo judicial como interferência indevida em área de atuação própria do poder político. Tese (Doutorado em Direito) - Universidade Federal de Santa Catarina. Florianópolis, 2011, p. 179. 
FONSECA, Lorena; COUTO, Felipe Fróes. Judicialização da Política e ativismo judicial: uma diferenciação necessária. Revista Eletrônica Direito e Política, Programa de Pós-Graduação Stricto Sensu em Ciência Jurídica da UNIVALI, Itajaí, v.13, n.2, 20 quadrimestre de 2018. Disponível em: www.univali.br/direitoepolitica - ISSN 1980-7791

Neste caso, o que se questiona não é a legitimidade ou necessidade - compreendemos que se trata de uma questão que não poderia ficar sem o devido amparo jurídico -, contudo, nossa democracia tem como pressuposto a participação de numerosos segmentos na tomada de suas decisões fundamentais e, ainda que a causa seja justa, deveria um tribunal, através de um ato investido de autoridade (e vontade), decidir de modo a criar um arcabouço jurídico?

Isto posto, a judicialização da política mostra-se como um "fenômeno contingencial e inexorável"16, ao passo que o ativismo judicial consolida-se como uma "postura, um comportamento de juízes e tribunais, que, através de um ato de vontade, isto é, de um critério não jurídico, proferem seus julgamentos, extrapolando os limites de sua atuação"17. A judicialização e o ativismo judicial podem até se complementar, posto que a judicialização da política talvez gere condutas cada vez mais proativas dos magistrados, mas tem definições distintas.

Feita a diferenciação entre os conceitos de judicialização e de ativismo e, adotando-se a perspectiva que os fenômenos são conexos, mas de "famílias diferentes", passemos agora à análise das causas diversas que ensejaram um e outro fenômeno.

\section{AS ORIGENS DA JUDICIALIZAÇÃO POLÍTICA E SOCIAL}

A judicialização se caracteriza pela atuação do poder judiciário em áreas que eram tradicionalmente ocupadas pelo parlamento, contudo, esse fenômeno provoca questionamentos quanto à legitimidade do papel exercido pelos Juízes em substituição à atuação política do Poder Legislativo ${ }^{18}$.

Tal tendência judicializante, que vem ocorrendo por conta da maior consagração de direitos e regulamentações constitucionais, é comum nas sociedades atuais e um traço típico das democracias de massa. Todavia, o ponto central a ser enfatizado é que sua

\footnotetext{
${ }^{16}$ TASSINARI, Clarissa. Ativismo judicial: uma análise da atuação do judiciário nas experiências brasileira e norte-americana, p. 128.

17 TASSINARI, Clarissa. Ativismo judicial: uma análise da atuação do judiciário nas experiências brasileira e norte-americana, p. 128.

18 SURGIK, Aloisio; WACHELESKI, Marcelo Paulo. O Poder Judiciário e as decisões políticas: uma crítica a partir da teoria procedimentalista. Revista Eletrônica Direito e Política, Programa de Pós Graduação Stricto Sensu em Ciência Jurídica da UNIVALI, Itajaí, v. 9, n. 3, p. 1854, $3^{\circ}$ quadrimestre de 2014.
} 
FONSECA, Lorena; COUTO, Felipe Fróes. Judicialização da Política e ativismo judicial: uma diferenciação necessária. Revista Eletrônica Direito e Política, Programa de Pós-Graduação Stricto Sensu em Ciência Jurídica da UNIVALI, Itajaí, v.13, n.2, $2^{\circ}$ quadrimestre de 2018. Disponível em: www.univali.br/direitoepolitica - ISSN 1980-7791

manifestação não obedece, diretamente, aos desejos do órgão judicante. Na verdade, ela é fruto de contingências político-sociais, as quais serão apontadas a seguir ${ }^{19}$. Abordaremos alguns dos principais acontecimentos que conduziram as sociedades contemporâneas a vivenciar este processo de intensa judicialização.

\subsection{PóS-GUERRA E O CONSTITUCIONALISMO DIRIGENTE}

O período posterior à Segunda Guerra Mundial é considerado um marco para o Direito no mundo todo, pois foi nele que se rompeu com toda a estrutura legislativa que atribuía legitimidade à existência dos regimes totalitários, responsáveis por diversas atrocidades $^{20}$.

O fim desta Guerra impulsionou um rearranjo institucional que buscava assegurar direitos fundamentais constitucionalmente, configurando-se, assim, a transição do que se conhecia por Estado Legislativo de Direito para um Estado Constitucional de Direito ${ }^{21}$.

Essa transição se deu porque superou-se a função da Constituição de apenas estabelecer o procedimento para a produção legislativa e de atos do Poder Público, transformando-a em juridicamente vinculante, ao prever direitos fundamentais que determinam o conteúdo dessa produção legislativa 22 .

Segundo Konrad Hesse ${ }^{23}$, as Constituições do Segundo Pós-Guerra, mais do que simples "folhas de papel", como preceituava Ferdinand Lassalle, possuíam "Força Normativa", vinculando diretamente as relações entre sociedade e Estado.

Fora assim que o constitucionalismo passou a ser concebido de maneira nova, sendo percebido sob o viés da materialidade. Foram incluídos dois elementos centrais: "o reconhecimento da força normativa da Constituição $[\ldots]$ que condiciona materialmente

\footnotetext{
19 TOMAZ DE OLIVEIRA, Rafael et al.. Anais do X Simpósio Nacional de Direito Constitucional.

20 TASSINARI, Clarissa. Ativismo judicial: uma análise da atuação do judiciário nas experiências brasileira e norte-americana.

${ }^{21}$ FERRAJOLI, Luigi. Sobre los derechos fundamentales. Tradução de Miguel Carbonell. In: CARBONELL, Miguel (Org.). Teoría del neoconstitucionalismo: ensayos escogidos. Madrid: Trotta, 2007.

22 tOMAZ DE OLIVEIRA. Anais do X Simpósio Nacional de Direito Constitucional, p. 274.

${ }^{23}$ HESSE, Konrad. A Força Normativa da Constituição. Trad. Gilmar Ferreira Mendes. Porto Alegre: Safe, 1991.
} 
FONSECA, Lorena; COUTO, Felipe Fróes. Judicialização da Política e ativismo judicial: uma diferenciação necessária. Revista Eletrônica Direito e Política, Programa de Pós-Graduação Stricto Sensu em Ciência Jurídica da UNIVALI, Itajaí, v.13, n.2, $2^{\circ}$ quadrimestre de 2018. Disponível em: www.univali.br/direitoepolitica - ISSN 1980-7791

a legalidade; e da incorporação de [...] novos direitos aos cidadãos, com seus respectivos (instrumentos) assecuratórios"24.

Dito em outras palavras:

É a situação hermenêutica instaurada a partir do segundo pósguerra que proporciona o fortalecimento da jurisdição (constitucional), não somente pelo caráter hermenêutico que assume o direito, em uma fase pós-positivista e de superação do paradigma da filosofia da consciência, mas também pela força normativa dos textos constitucionais e pela equação que se forma a partir da inércia na execução de políticas públicas e na deficiente regulamentação legislativa de direitos previstos nas Constituições ${ }^{25}$.

Foi dessa forma que o constitucionalismo moldou um novo lugar para a Constituição e, como consequência, as instituições passaram a ser influenciadas pelo direito constitucional, o que permitiu uma aproximação com a democracia e inovou as formas de organização política. Esses avanços foram assimilados e concretizados na CF/88 e propostas teóricas, como a de José Joaquim Gomes Canotilho, foram absorvidas, colaborando para que se insurgisse um compromisso constitucional que resultou numa maior interferência do judiciário, voltada ao cumprimento do texto da Constituição.

Canotilho, autor do livro "Constituição Dirigente e Vinculação do Legislador", no qual se aprofundou na tese do jurista alemão Peter Lerche ("dirigierende Verfassug" de 1961), consagrou o que ficou conhecido como "Constitucionalismo dirigente". O autor demonstrou que as Constituições assumiram um papel de destaque, no sentido de que, ao "utilizar-se da expressão 'constituição dirigente', pretendeu-se [...] afirmar a força actuante do direito constitucional"26. Assim, extrai-se do texto constitucional a concepção de Estado de direito, passando a Constituição a ser "um meio de direção social e uma forma racionalizada de política"27.

\footnotetext{
24 TASSINARI, Clarissa. Ativismo judicial: uma análise da atuação do judiciário nas experiências brasileira e norte-americana, p. 29-30.

25 STRECK, Lenio Luiz. Verdade e Consenso, p. 190.

${ }^{26}$ CANOTILHO, José Joaquim Gomes. Constituição dirigente e vinculação do legislador: contributo para a compreensão das normas constitucionais programáticas. 2. ed. Coimbra: Coimbra Editora, 2001, p. 27.
}

27 CANOTILHO, José Joaquim Gomes. Constituição dirigente e vinculação do legislador, p. 48. 
FONSECA, Lorena; COUTO, Felipe Fróes. Judicialização da Política e ativismo judicial: uma diferenciação necessária. Revista Eletrônica Direito e Política, Programa de Pós-Graduação Stricto Sensu em Ciência Jurídica da UNIVALI, Itajaí, v.13, n.2, 20 quadrimestre de 2018. Disponível em: www.univali.br/direitoepolitica - ISSN 1980-7791

Neste sentido, Tomaz de Oliveira explica que a CF/88 possui capacidade de fomentar transformação social, primeiro por estabelecer diretrizes e objetivos a serem alcançados pelo Estado e, segundo, por vincular o legislador ordinário a realizar políticas públicas que reduzam as mazelas sociais presentes no Brasil28.

Nota-se, assim, que a CF/88 é do tipo dirigente, uma vez que define, "por meio das chamadas normas constitucionais programáticas, fins e programas de ação futura no sentido de melhoria das condições sociais e econômicas da população"29. A positividade jurídico-constitucional das normas programáticas significa fundamentalmente, segundo Canotilho:

(1) vinculação do legislador, de forma permanente, à sua realização (imposição constitucional); (2) vinculação positiva de todos os órgãos concretizadores, devendo estes tomá-las em consideração como directivas materiais permanentes, em qualquer dos momentos da actividade concretizadora (legislação, execução, jurisdição); (3) vinculação, na qualidade de limites materiais negativos, dos poderes públicos, justificando a eventual censura, sob a forma de inconstitucionalidade, em relação aos actos que as contrariam ${ }^{30}$.

Portanto, a "Constituição dirigente é o fundamento de legitimação política do Estado democrático de Direito" que garante força normativa a seus elementos e princípios, garante direitos fundamentais - individuais e sociais, conferindo-lhes caráter vinculante. ${ }^{31}$ Além disso, são estabelecidos "mecanismos de reivindicação pela efetivação desses elementos normativos via poder judiciário através de um superlativo mecanismo de controle de constitucionalidade" ${ }^{\prime 32}$.

É por isso que várias questões que anteriormente eram discutidas apenas no campo político, tornaram-se objeto de demanda judicial. Depois de reconhecida a força

\footnotetext{
28 TOMAZ DE OLIVEIRA, Rafael et al. Anais do X Simpósio Nacional de Direito Constitucional, p. 275.

${ }^{29}$ SILVA, José Afonso da. Aplicabilidade das Normas Constitucionais. 3 ed, São Paulo, Malheiros, 1998, p. 136.
}

${ }^{30}$ CANOTILHO, José Joaquim Gomes. Direito Constitucional e teoria da Constituição. 7 ed. Coimbra: Almedina, 2003, p. 1177.

31 TOMAZ DE OLIVEIRA, Rafael et al. Anais do X Simpósio Nacional de Direito Constitucional, p. 276.

32 TOMAZ DE OliveirA, Rafael et al. Anais do X Simpósio Nacional de Direito Constitucional, p. 276. 
FONSECA, Lorena; COUTO, Felipe Fróes. Judicialização da Política e ativismo judicial: uma diferenciação necessária. Revista Eletrônica Direito e Política, Programa de Pós-Graduação Stricto Sensu em Ciência Jurídica da UNIVALI, Itajaí, v.13, n.2, 20 quadrimestre de 2018. Disponível em: www.univali.br/direitoepolitica - ISSN 1980-7791

normativa da Constituição, a jurisdição constitucional ganhou espaço e passou a realçar os direitos fundamentais. A partir do momento que o poder judiciário começou a proteger esses direitos, em detrimento dos outros poderes, sua atuação se amplia. Os limites da discricionariedade do legislador ordinário também aumentam, mas agora eles estão vinculados aos objetivos dos programas constitucionais e também aos limites impostos pelos próprios direitos fundamentais.

\subsection{AUMENTO DA LITIGIOSIDADE E DAS DEMANDAS POR JUSTIÇA}

Como visto, o fenômeno da judicialização da política é produto das transformações ocorridas no Direito com o advento do novo texto constitucional. Além das razões expostas, Valle afirma que a constitucionalização do Direito após a $2^{\text {a }}$ Guerra Mundial, a legitimação dos Direitos Humanos e as influências dos sistemas Norte-americano e Europeu são fatores que contribuíram fortemente para a concretização do fenômeno da judicialização do sistema político, inclusive o Brasileiro ${ }^{33}$.

Leite afirma, neste sentido, que:

A criação de órgãos internacionais de defesa dos direitos humanos, em especial a Convenção Européia para Proteção dos Direitos Humanos, influenciou o processo de judicialização da política, pois os parlamentos dos países que participaram daquela Convenção foram obrigados a adequar suas legislações às exigências relativas aos direitos dos respectivos cidadãos ${ }^{34}$.

Assim, a CF/88 mostra-se como resultado da conjunção entre a sociedade, esfera política e contexto histórico. Segundo Surgik e Wacheleski, no Brasil, os movimentos sociais antiautoritarismo a partir da década de 70, procuraram consolidar direitos humanos bem como os direitos econômicos e sociais. Segundo os autores, "os problemas políticos foram codificados e ganharam estrutura normativa de princípios, com normas assecuratórias de seu cumprimento" 35 .

33 VALLE, Vanice Regina Lírio do (Org.). Ativismo jurisdicional e o Supremo Tribunal Federal: laboratório de Análise Jurisprudencial do STF. Curitiba: Juruá, 2009, p. 32.

\footnotetext{
${ }^{34}$ LEITE, Roberto Basilone. Déficit político do poder judiciário brasileiro: A falta de efetividade no desempenho de suas funções institucionais e o ativismo judicial como interferência indevida em área de atuação própria do poder político, p. 181.
}

35 SURGIK, Aloisio; WACHELESKI, Marcelo Paulo. Revista Eletrônica Direito e Política, Programa de Pós Graduação Stricto Sensu em Ciência Jurídica da UNIVALI, p. 1857. 
FONSECA, Lorena; COUTO, Felipe Fróes. Judicialização da Política e ativismo judicial: uma diferenciação necessária. Revista Eletrônica Direito e Política, Programa de Pós-Graduação Stricto Sensu em Ciência Jurídica da UNIVALI, Itajaí, v.13, n.2, 20 quadrimestre de 2018. Disponível em: www.univali.br/direitoepolitica - ISSN 1980-7791

Com isso, podemos notar mudanças significativas em duas frentes: por um lado "ampliou-se o catálogo de direitos aos cidadãos (com o fito de se criar uma política de bem-estar); por outro, assentou-se o dever de cumprir de modo imediato este programa constitucional (objetivando torná-la efetiva)"36.

Por isso a justiça constitucional é, muitas vezes, chamada a atuar como protetora de indivíduos, de minorias étnicas, de parlamentares que tenham seus direitos ofendidos ou sejam impedidos de participar do processo político nos casos em que não é possível controle sobre as ações da maioria ${ }^{37}$. Nota-se que esses fenômenos convergiram para que houvesse mais participação do Estado, mas que, diante da inércia dos demais poderes, deu-se margem para a Jurisdição suprimir lacunas, passando o Judiciário a exercer um papel determinante na definição de determinados padrões a serem respeitados $^{38}$.

Contudo, todas essas transformações não se restringem à maior procura do judiciário, caracterizado como ambiente propício para concretização dos direitos previstos e não cumpridos pelos demais Poderes. Essas mudanças são reforçadas pelo aumento da conflituosidade da sociedade que a todo tempo demanda soluções, principalmente do judiciário.

Habermas, ${ }^{39}$ ao tratar da colonização sistêmica do mundo da vida, expôs que a sociedade, em sua essência, tem sido colonizada sistemicamente, ou seja, no âmbito do sistema jurídico há demandas por soluções cada vez mais intensas na família, na economia, na saúde, na política e na educação. O que ocorre é que a transformação da sociedade exige soluções do sistema jurídico. A diversidade sexual, por exemplo, uma vez tendo sido problematizada tardiamente na sociedade estruturalmente

\footnotetext{
36 TASSINARI, Clarissa. Ativismo judicial: uma análise da atuação do judiciário nas experiências brasileira e norte-americana, p. 33.

37 LEITE, Roberto Basilone. Déficit político do poder judiciário brasileiro: A falta de efetividade no desempenho de suas funções institucionais e o ativismo judicial como interferência indevida
} em área de atuação própria do poder político.

38 TASSINARI, Clarissa. Ativismo judicial: uma análise da atuação do judiciário nas experiências brasileira e norte-americana.

39 HABERMAS, Jürgen. Teoría de la acción comunicativa. 2. ed. Madrid: Taurus, 2001, p. 451-468. 
FONSECA, Lorena; COUTO, Felipe Fróes. Judicialização da Política e ativismo judicial: uma diferenciação necessária. Revista Eletrônica Direito e Política, Programa de Pós-Graduação Stricto Sensu em Ciência Jurídica da UNIVALI, Itajaí, v.13, n.2, 20 quadrimestre de 2018. Disponível em: www.univali.br/direitoepolitica - ISSN 1980-7791

patriarcal, "gera crises de compreensão e polêmicas de inúmeras ordens - direitos patrimoniais e previdenciários dos conviventes e direito à adoção"40.

Neste sentido, Tassinari afirma que:

O contexto social passa também por modificações, que podem ser ditas de cunho político-jurídico (chamadas de "tendências no Direito"), conceitual (com a introdução da noção de sociedade complexa), comportamental (com a questão do aumento da litigiosidade) e estrutural (a partir da ideia de massificação dos conflitos). Ou seja, o fenômeno de judicialização não ocorreu exclusivamente porque, com a promulgação de novos textos, há maiores possibilidades jurídicas de exigências judiciais; é necessário agregar a isso os diferentes contornos que assumiu a esfera social. ${ }^{41}$

Além disso, regimes democráticos acentuam a conflituosidade social, porque neles a distribuição do poder é feita de forma mais ampla e difusa. E, em existindo mais centros de poder, há uma chance maior de surgirem conflitos que têm sido encaminhados para que o judiciário resolva ${ }^{42}$.

Por fim, outra questão que contribui para a expansão do poder judicial é a transferência do poder de decisão das instituições majoritárias para os tribunais. Muitas vezes, "a solução de assuntos polêmicos [...] acaba sendo transferida para a autoridade judicial porque o custo da decisão é muito alto e pode prejudicar a imagem do político e suas pretensões eleitorais"43. Dessa maneira, o uso da jurisdição evita as consequências de uma decisão politicamente desgastante.

As condições acima expostas estimulam o fenômeno da judicialização da política. Alguns estudiosos defendem que esses fatores só trazem alguma implicação negativa

\footnotetext{
40 RIBEIRO, Diógenes V. Hassan. Judicialização e desjudicialização, entre a deficiência do legislativo e a insuficiência do judiciário. Revista de Informação Legislativa. Ano 50, Número 199, jul./set., p. 27, 2013.

41 TASSINARI, Clarissa. Ativismo judicial: uma análise da atuação do judiciário nas experiências brasileira e norte-americana, p. 34.

42 CADEMARTORI, Daniela Mesquista Leutchuk de. O diálogo democrático: Alain Touraine, Noberto Bobbioe Robert Dahl. Curitiba: Juruá, 2006.

${ }^{43}$ LEITE, Roberto Basilone. Déficit político do poder judiciário brasileiro: A falta de efetividade no desempenho de suas funções institucionais e o ativismo judicial como interferência indevida em área de atuação própria do poder político, p. 182.
} 
FONSECA, Lorena; COUTO, Felipe Fróes. Judicialização da Política e ativismo judicial: uma diferenciação necessária. Revista Eletrônica Direito e Política, Programa de Pós-Graduação Stricto Sensu em Ciência Jurídica da UNIVALI, Itajaí, v.13, n.2, 20 quadrimestre de 2018. Disponível em: www.univali.br/direitoepolitica - ISSN 1980-7791

se os juízes adotam uma postura ativista, posicionamento que exploraremos na sequência.

\section{AS ORIGENS DO ATIVISMO JUDICIAL}

Como visto, a judicialização é um fenômeno que se manifesta na esfera jurídica, porém não é próprio do Direito, pois envolve toda uma construção de um imaginário social e político que ultrapassa as fronteiras do seu âmbito de atuação. Por outro lado, "o ativismo judicial revela-se como um problema exclusivamente jurídico (ou seja, criado pelo Direito, mas, evidentemente, com consequências em todas as demais esferas)"44. Assim, ao se questionar como se compreende a manifestação judiciária, "é possível encontrar posicionamentos que retrataram a indexação da decisão judicial a um ato de vontade daquele que julga"45.

Foi Hans Kelsen no capítulo VIII da "Teoria Pura do Direito" que estabeleceu a diferença entre Direito e Ciência do Direito e, com isso, em cada um desses âmbitos, trouxe uma forma diferenciada de compreender a questão hermenêutica ${ }^{46}$. O debate sobre ativismo não era centro da teoria Kelsiana, cujo enfoque é a construção da Ciência do Direito, mas as distinções feitas por ele nos permitem entender algumas questões conexas, como se verá a seguir.

Kelsen ${ }^{47}$ diferencia o ato de interpretar do Cientista do Direito do que é praticado pelo Aplicador do Direito (órgão jurídico), porque este é definido como um ato de vontade e aquele como um ato de conhecimento.

Segundo Tassinari, baseada em Kelsen, os efeitos disso são:

(1) a afirmação de que, como resultado da interpretação realizada pelos órgãos jurídicos, tem-se normas jurídicas (diferente da interpretação do cientista do direito, que produz proposições); (2) a afirmativa de que a interpretação dos órgãos jurídicos são as únicas consideradas autênticas; (3) que estas,

\footnotetext{
44 TASSINARI, Clarissa. Ativismo judicial: uma análise da atuação do judiciário nas experiências brasileira e norte-americana, p. 43-44.

45 TASSINARI, Clarissa. Ativismo judicial: uma análise da atuação do judiciário nas experiências brasileira e norte-americana, p. 43-44.

46 KELSEN, Hans. Teoria pura do direito. Tradução de João Baptista Machado. São Paulo: Martins Fontes, 1999.

47 KELSEN, Hans. Teoria pura do direito.
} 
FONSECA, Lorena; COUTO, Felipe Fróes. Judicialização da Política e ativismo judicial: uma diferenciação necessária. Revista Eletrônica Direito e Política, Programa de Pós-Graduação Stricto Sensu em Ciência Jurídica da UNIVALI, Itajaí, v.13, n.2, 20 quadrimestre de 2018. Disponível em: www.univali.br/direitoepolitica - ISSN 1980-7791

também, são as que criam direito; e, por fim, (4) que este ato de vontade está eivado de discricionariedade ${ }^{48}$.

Dessa forma, verifica-se que o problema do ativismo está no âmbito da Teoria do Direito, porque estamos tratando de um ato de vontade do juiz/tribunal. Tomaz de Oliveira retoma associa ativismo com "vontade do intérprete" no momento da concreção do direito e afirma que o gérmen do ativismo está mesmo no normativismo Kelsiano. O autor explica, didaticamente, que:

A construção epistemológica kelseniana está alicerçada na clássica dicotomia razão v.s. vontade. Assim, todas as questões reivindicadas pelos interesses, finalidades, etc. Kelsen atira para dentro daquilo que ele chamou de "política jurídica", que se manifesta, em termos kelsenianos, na interpretação que os órgãos jurídicos competentes formulam sobre o direito. Portanto, são reunidos no interior da esfera de atos voluntaristas daqueles que lidam com o direito; ao passo que a ciência do direito se interessa pelo conhecimento das normas jurídicas (e não de sua "aplicação"), sendo que essa interpretação é regulada por determinados pressupostos lógico sistemáticos desenvolvidos no ambiente de sua teoria pura. Nesse aspecto, portanto, Kelsen se movimenta em um metadiscurso que fornece uma interpretação logicamente rigorosa do complexo "mundo normativo". Assim, Kelsen retoma a ideia de um sistema estruturado a partir de uma rigorosa cadeia lógico-dedutiva, mas que não se encontra atrelado à atividade das autoridades - orgãos - que efetivamente "aplicam" as normas jurídicas ${ }^{49}$.

Portanto, fica evidenciada a relação entre vontade e discricionariedade, porque Kelsen aponta no sentido de que a interpretação dos órgãos judiciários são atos de vontade e que o ato aplicativo do direito tem caráter discricionário. Isso permite a diferenciação entre judicialização da política de ativismo judicial e convalida "a tese de que no conteúdo do ativismo judicial está incluído o problema da vontade como critério decisório"50. Diferente da judicialização, que o judiciário não promove, não tem origem no desejo do julgador, sendo fruto de um incidente de deslocamento da Democracia e do Estado para os tribunais.

\footnotetext{
48 TASSINARI, Clarissa. Ativismo judicial: uma análise da atuação do judiciário nas experiências brasileira e norte-americana, p. 46-47.

49 TOMAZ DE OLIVEIRA, Rafael et al. Anais do X Simpósio Nacional de Direito Constitucional, p. 284.

50 TASSINARI, Clarissa. Ativismo judicial: uma análise da atuação do judiciário nas experiências brasileira e norte-americana, p. 47.
} 
FONSECA, Lorena; COUTO, Felipe Fróes. Judicialização da Política e ativismo judicial: uma diferenciação necessária. Revista Eletrônica Direito e Política, Programa de Pós-Graduação Stricto Sensu em Ciência Jurídica da UNIVALI, Itajaí, v.13, n.2, $2^{\circ}$ quadrimestre de 2018. Disponível em: www.univali.br/direitoepolitica - ISSN 1980-7791

Feitas as indicações do âmbito no qual estão situadas as questões relacionadas ao ativismo judicial, passemos agora às possíveis origens do fenômeno. Iniciaremos pela linha divisória entre judicialização e ativismo traçada por Garapon, depois faremos uma breve incursão nas experiências de ativismo dos EUA e da Alemanha.

\subsection{JUDICIALIZAÇÃO E ATIVISMO EM ANTOINE GARAPON}

Através da leitura da obra "O guardador de promessas" do Antoine Garapon ${ }^{51}$, fica claro o surgimento de um ambiente caracterizado por uma intensa atividade jurisdicional, bem como de uma transposição deste fenômeno para o que ficou conhecido como ativismo judicial. Dessa forma, torna-se possível diferenciar a configuração de uma tendência judicializante para as posturas consideradas ativistas.

Garapon afirma que a judicialização pode ser contextualizada, em resumo: (1) por uma descrença na lei e por um aumento na dimensão interpretativa do Direito consequentemente; (2) por uma desestruturação do conceito de democracia, desaparecendo a figura do "homem democrático"; e (3) pelo surgimento dos sistemas supranacionais, que fragilizaram a concepção de soberania estatal, mas possibilitaram o surgimento de novas instâncias jurisdicionais, como as Cortes de Direitos Humanos 52 .

Assim há uma "promoção" da atividade jurisdicional e isso representa uma substituição da positividade por uma "justiciabilidade", no sentido de que o Direito passa a se definir "pela possibilidade de submeter um comportamento à apreciação de um terceiro", no caso, o Judiciário ${ }^{53}$.

Já o ativismo tem outro contorno, a atuação jurisdicional é acentuada de tal forma que os juízes passam a ser considerados como "últimos ocupantes de uma função de autoridade - clerical e até paternal - abandonada por seus antigos titulares" 54 .

\footnotetext{
51 GARAPON, Antoine. O guardador de promessas: justiça e democracia. Tradução de Francisco Aragão. Lisboa: Instituto Piaget, 1998.

52 GARAPON, Antoine. O guardador de promessas, p. 20-25.

53 GARAPON, Antoine. O guardador de promessas, p. 40-43.

54 GARAPON, Antoine. O guardador de promessas, p. 20-25.
} 
FONSECA, Lorena; COUTO, Felipe Fróes. Judicialização da Política e ativismo judicial: uma diferenciação necessária. Revista Eletrônica Direito e Política, Programa de Pós-Graduação Stricto Sensu em Ciência Jurídica da UNIVALI, Itajaí, v.13, n.2, 20 quadrimestre de 2018. Disponível em: www.univali.br/direitoepolitica - ISSN 1980-7791

É neste contexto que Garapon associa a decisão judicial a um critério de desejo, de vontade daquele que julga, afirmando: "o ativismo começa quando, entre várias soluções possíveis, a escolha do Juiz é dependente do desejo de acelerar a mudança social ou, pelo contrário, de a travar". Dessa forma, podemos notar que o ativismo se evidencia de duas maneiras ou sob a forma de um "novo clericalismo dos juristas, se a corporação dos juízes for poderosa, ou, pelo contrário, sob a forma de algumas individualidades sustentadas pelos media, se a magistratura não tiver grande tradição de independência" ${ }^{\prime 5}$.

Isto posto, o trabalho de Garapon explicita que "a centralidade da jurisdição não aparece, apenas, como um fenômeno social, mas como uma tomada de postura de juízes e tribunais na afirmação de suas vontades" - ou, nas palavras do autor, "desejos". Além disso, o autor "possibilita diferenciar ativismo judicial de judicialização, o que é imprescindível para que se possa problematizar a atuação jurisdicional"56.

\subsection{A EXPERIÊNCIA NORTE-AMERICANA DE ATIVISMO JUDICIAL}

O sistema de common law, aliado à tradição republicana dos EUA, trouxe importantes contribuições para o processo de tribunalização da política, através do judicial review. Mesmo diante da inexistência de previsão expressa de controle de constitucionalidade das leis norte-americanas pelo poder judiciário, reconhece-se o pioneirismo do país no judicial review ${ }^{57}$.

Por isso a abordagem sobre atuação do poder judiciário nos Estados Unidos da América revela-se importante:

Primeiro, porque foi no seio da tradição jurídica estadunidense que surgiram as discussões sobre ativismo judicial; segundo, porque na mudança do papel assumido pela jurisdição no constitucionalismo democrático no Brasil a doutrina brasileira passou a incorporar a expressão ativismo judicial, algumas vezes acompanhada (senão fundamentada) pelos aportes teóricos

\footnotetext{
55 GARAPON, Antoine. 0 guardador de promessas, p. 54.

56 TASSINARI, Clarissa. Ativismo judicial: uma análise da atuação do judiciário nas experiências brasileira e norte-americana, p. 49.

57 MELO, Manuel Palacios Cunha. A Suprema Corte dos EUA e a judicialização da política: notas sobre um itinerário difícil. In: VIANNA, Luiz Werneck (org.) A democracia e os três poderes no Brasil, 2002, p. 67.
} 
FONSECA, Lorena; COUTO, Felipe Fróes. Judicialização da Política e ativismo judicial: uma diferenciação necessária. Revista Eletrônica Direito e Política, Programa de Pós-Graduação Stricto Sensu em Ciência Jurídica da UNIVALI, Itajaí, v.13, n.2, 20 quadrimestre de 2018. Disponível em: www.univali.br/direitoepolitica - ISSN 1980-7791

norte-americanos; terceiro $[\ldots]$, importa analisar quais as possibilidades de realizar esta transposição de teorias ao Direito brasileiro ${ }^{58}$.

É possível identificar três Eras distintas no Constitucionalismo norte-americano, levando-se em consideração a postura da Suprema Corte na jurisdição constitucional nesses mais de 200 anos de história ${ }^{59}$.

Segundo Wolfe, a "traditional era" se inicia com o estabelecimento da Constituição e perdura até 1890. A era intermediária, chamada de "transitional era", começa com o fim da primeira e não tem seu término precisamente esclarecido. Isso porque, em 1937, ainda com reflexos da política do New Deal, ocorreram mudanças na forma de interferência judicial. Apesar disso, não há certeza de que estas alterações foram significativas a ponto de ensejarem o início de um novo período, a nomeada "modern era", atual momento do Judiciário dos EUA ${ }^{60}$.

No contexto da primeira Era inaugura-se o controle difuso de constitucionalidade das leis (judicial review). A origem do judicial review é objeto de muitos questionamentos teóricos. Não obstante, entre as discussões desenvolvidas, há pelo menos um ponto comum: de que a sentença proferida por Chief Justice Marshall, no famoso caso Marbury vs. Madison foi uma manifestação do poder da Corte em revisar uma decisão política ${ }^{61}$.

O resumo do caso Marbury vs. Madison, pode ser assim feito: John Adams, presidente dos Estados Unidos, na véspera de deixar o cargo, designou que William Marbury ocupasse o cargo de Juiz de paz, entretanto, Thomas Jefferson, sucessor na presidência, não reconheceu o desígnio de Adams. Marbury recorreu à Suprema Corte para que James Madison, então Secretário de Estado, o empossasse como Juiz de paz com base na seção 13 do Judiciary Act de 1789. No entanto, em 1802, o Congresso revogou o Judiciary Act. Então, ciente de que se fosse concedido o mandado a decisão

\footnotetext{
58 TASSINARI, Clarissa. Ativismo judicial: uma análise da atuação do judiciário nas experiências brasileira e norte-americana, p. 52/53.

59 WOLFE, Christopher. The rise of modern judicial review: From constitutional interpretation to judge-made law. Boston: Littlefield Adams Quality Paperbacks, 1994.

60 WOLFE, Christopher. The rise of modern judicial review, p. 3-11.

61 TASSINARI, Clarissa. Ativismo judicial: uma análise da atuação do judiciário nas experiências brasileira e norte-americana.
} 
FONSECA, Lorena; COUTO, Felipe Fróes. Judicialização da Política e ativismo judicial: uma diferenciação necessária. Revista Eletrônica Direito e Política, Programa de Pós-Graduação Stricto Sensu em Ciência Jurídica da UNIVALI, Itajaí, v.13, n.2, 20 quadrimestre de 2018. Disponível em: www.univali.br/direitoepolitica - ISSN 1980-7791

poderia não ser cumprida, Marshall estabeleceu que Marbury tinha direito de ser empossado, tendo em vista que a nomeação era irrevogável. Mas negou que a Suprema Corte poderia julgar o caso, pois a seção 13 do Judiciary Act, que lhe atribuía tal competência, era inconstitucional, na medida em que ampliava a competência da Suprema Corte estabelecida constitucionalmente ${ }^{62}$.

Vê-se, portanto, que nessa primeira Era - chamada Era Tradicional, o poder judiciário é exercido com o objetivo de efetivar a vontade da lei e não a vontade do julgador. Por isso, há busca pela interpretação das palavras, do contexto, da matéria e da intenção dos autores da Constituição, no entanto, essa interpretação não é um processo mecânico da aplicação, pois o julgador deverá perseguir o caráter substancial da constituição para encontrar a interpretação correta63.

Já na Transitional Era os reflexos da política do New Deal impõem modificações no modo de interferência judicial desempenhado pela Suprema Corte. Por influência do laissez-faire, a Suprema Corte impediu o Estado de tomar quaisquer medidas voltadas à regulação, por exemplo, das políticas de bem-estar relativas à segurança, à saúde, ao trabalho, etc ${ }^{64}$.

Nesse sentido, cumpre fazer referência ao famoso caso Lochner $v$. New York (198 U.S. 45), em 1905, no qual a Suprema Corte invalidou uma lei estadual do estado de New York, que limitava a jornada de trabalho dos empregados de padaria, por considerá-la intrusiva demais na política econômica do Estado65.

Essa tendência conservadora da segunda Era, na qual a Suprema Corte impossibilitava a interferência do Estado na esfera das relações privadas, ficou conhecida como uma política judiciária de contenção (self-restraint). Segundo Wolfe, nessa era de transição,

\footnotetext{
62 LEVY, Leonard W. Marbury v. Madison. In: KARST, Kenneth L; MAHONEY, Dennis J. (Orgs.). Judicial Power and the Constitution: selections from the Encyclopedia of the American Constitution. New York: Macmillan, 1990, p. 15-20.

${ }^{63}$ WOLFE, Christopher. The rise of modern judicial review, p. 76-79.

64 TRINDADE, André Karam; MORAIS, Fausto Santos de. Ativismo judicial: As experiências norteamericana, alemã e brasileira. Revista da Faculdade de Direito - UFPR, Curitiba, n. 47, p. 137-164, 2011.

65 SCHWARTZ, Bernard. A book of legal lists: the best and worst in american law. Oxford: Oxford University Press, 1997, p. 118-119.
} 
FONSECA, Lorena; COUTO, Felipe Fróes. Judicialização da Política e ativismo judicial: uma diferenciação necessária. Revista Eletrônica Direito e Política, Programa de Pós-Graduação Stricto Sensu em Ciência Jurídica da UNIVALI, Itajaí, v.13, n.2, $2^{\circ}$ quadrimestre de 2018. Disponível em: www.univali.br/direitoepolitica - ISSN 1980-7791

a atuação da Suprema Corte é marcada por uma questão de vontade - que se sobrepõe à questão da interpretação verificada na era tradicional66.

Tassinari afirma que, apesar da política judiciária de contenção, ainda é possível perceber uma postura ativista, isso porque haviam traços altamente políticos nas decisões da Suprema Corte que invadiam o âmbito de produção legislativa. O que deixa "claro que, mesmo um comportamento conservador do Judiciário, de não intervenção, pode revelar um perfil ativista"67.

Como se sabe, a crise econômica que resultou na quebra da bolsa em 1929 mudou a conjuntura político-social, o que levou o governo dos EUA estabelecer várias medidas reguladoras. Entretanto, os cinco juízes que compunham a Suprema Corte se insurgiram contra o plano econômico de Roosevelt, então Presidente. A corte invocava a cláusula do devido processo e a cláusula do comércio para derrubar grande parte da legislação proposta pelo governo, inviabilizando o desenvolvimento de uma política progressista. Diante disso, Roosevelt anunciou em 5/2/1937 o seu plano de aumentar mais uma vaga na Suprema Corte para cada Juiz que ultrapassasse 70 anos de idade e, assim, conseguiu fazer com que a Corte finalmente se rendesse e, sem que tenha ocorrido sequer uma nomeação, mudasse sua jurisprudência, passando a compactuar com as medidas de recuperação da economia propostas pelo governo ${ }^{68}$.

Desse modo, a Suprema Corte passou a presumir a constitucionalidade de toda legislação que intervinha no domínio econômico, adotando o que se convencionou chamar rational basis test, exigindo-se apenas que as leis fossem razoavelmente relacionadas a um objetivo político válido para que não tivessem sua invalidade decretada. É nesse contexto que se inicia a terceira Era69.

Na Era Moderna - Terceira Era, a Suprema Corte deslocou o foco do ativismo da esfera econômica para as liberdades civis. A expressão da Suprema Corte cresceu e os juízes,

\footnotetext{
66 WOLFE, Christopher. The rise of modern judicial review, p. 4-5.

67 TASSINARI, Clarissa. Ativismo judicial: uma análise da atuação do judiciário nas experiências brasileira e norte-americana, p. 74-75.

68 TRINDADE, André Karam; MORAIS, Fausto Santos de. Revista da Faculdade de Direito - UFPR.

69 TRINDADE, André Karam; MORAIS, Fausto Santos de. Revista da Faculdade de Direito - UFPR.
} 
FONSECA, Lorena; COUTO, Felipe Fróes. Judicialização da Política e ativismo judicial: uma diferenciação necessária. Revista Eletrônica Direito e Política, Programa de Pós-Graduação Stricto Sensu em Ciência Jurídica da UNIVALI, Itajaí, v.13, n.2, 20 quadrimestre de 2018. Disponível em: www.univali.br/direitoepolitica - ISSN 1980-7791

inseridos na tradição da common law, deixaram de simplesmente interpretar as leis e passaram a reescrevê-las ${ }^{70}$.

O perfil ativista atingiu ápice entre 1953 e 1969, período em que a Corte era presidida pelo Juiz Earl Warren. Ele se opôs à postura self-restraint, preponderante antes de sua nomeação, e se posicionou a favor do ativismo judicial para compensar as deficiências do processo político democrático ${ }^{71}$.

Esse perfil mostrou-se sobressalente, "marcado por uma postura ativista - que se concentra, sobretudo, na preservação dos direitos e garantias fundamentais"72, até mesmo depois da aposentadoria de Warren, quando Nixon nomeia seu sucessor, o Juiz Warren E. Burger. A Corte Burger, diferente do que se esperava, não conseguiu impedir o liberalismo do Juiz William Brennan Jr. e manteve a grande maioria das decisões rotuladas de ativistas ${ }^{73}$.

Conforme ensinam Trindade e Morais:

A Suprema Corte voltou a assumir um perfil moderadamente conservador somente a partir de 1986 -, quando Ronald Reagan nomeou o então juiz William $\mathrm{H}$. Rehnquist presidente da Corte, cujo legado foi a defesa do federalismo contra a centralização do governo federal, além da maior alteração de precedentes da história da Corte $^{74}$.

Com a morte do Juiz Rehnquist, em 2005, o presidente George W. Bush nomeou o Juiz John Roberts Jr. Este assumiu a presidência da Suprema Corte e vem interpretando a constituição de forma originalista, isto é, uma "interpretação baseada na objetividade do texto e na ideia de que seu o sentido deve ser orientado a partir

\footnotetext{
70 WOLFE, Christopher. The rise of modern judicial review, p. 6-7.

${ }^{71}$ SCHWARTZ, Bernard. The Warren Court: a retrospective. Oxford: Oxford University Press, 1996, p. 258.

72 DWORKIN, Ronald. Levando os direitos a sério. São Paulo: Martins Fontes, 2002, p. 220-234.

73 MICHELMAN, Frank. La democrazia e il potere giudiziario: il dilemma costituzionale e il giudice Brennan. Bari: Dedalo, 2004. 142.

74 TRINDADE, André Karam; MORAIS, Fausto Santos de. Revista da Faculdade de Direito - UFPR, p.
} 
FONSECA, Lorena; COUTO, Felipe Fróes. Judicialização da Política e ativismo judicial: uma diferenciação necessária. Revista Eletrônica Direito e Política, Programa de Pós-Graduação Stricto Sensu em Ciência Jurídica da UNIVALI, Itajaí, v.13, n.2, $2^{\circ}$ quadrimestre de 2018. Disponível em: www.univali.br/direitoepolitica - ISSN 1980-7791

dos autores da Constituição, no caso norte-americano, os Framers"75. (grifo não original)

Devido ao exposto, podemos aduzir que o ativismo judicial pode assumir as mais variadas formas e que, por isso, não deve ser relacionado, exclusivamente, com uma intervenção positiva pela Suprema Corte ${ }^{76}$. Além disso, esse breve histórico indica que é não é viável tratar do fenômeno do "ativismo judicial - diretamente ligado ao problema da interpretação da Constituição - de um modo monolítico, desconsiderando as vicissitudes históricas que giram em torno do exercício constante da judicial review"77.

Isso porque as modificações ocorridas nos modos de controle de constitucionalidade norte-americano ocorreram de forma gradativa. E não poderia ser diferente, pois "de algum modo o crescimento da judicial review e o desenvolvimento de suas técnicas interpretativas se confunde em muitos aspectos com a própria história do direito constitucional estadunidense" 78 .

Assim, o que se pode extrair desse sucinto histórico é que o ativismo judicial advindo da jurisprudência norte-americana iniciou conservador e fora ficando progressista, passando por contínuo desenvolvimento constitucional com modelos hermenêuticos que asseguram uma interpretação racionalmente construída a partir de princípios substantivos.

\footnotetext{
75 TRINDADE, André Karam; MORAIS, Fausto Santos de. Revista da Faculdade de Direito - UFPR, p. 143-144.

76 DWORKIN, Ronald. Levando os direitos a sério, p. 215-231.

77 TOMAZ DE OLIVEIRA, Rafael et al. Anais do X Simpósio Nacional de Direito Constitucional, p. 292-293.

78 TOMAZ DE OLIVEIRA, Rafael et al. Anais do X Simpósio Nacional de Direito Constitucional, p. 292.
} 
FONSECA, Lorena; COUTO, Felipe Fróes. Judicialização da Política e ativismo judicial: uma diferenciação necessária. Revista Eletrônica Direito e Política, Programa de Pós-Graduação Stricto Sensu em Ciência Jurídica da UNIVALI, Itajaí, v.13, n.2, $2^{\circ}$ quadrimestre de 2018. Disponível em: www.univali.br/direitoepolitica - ISSN 1980-7791

\subsection{A EXPERIÊNCIA ALEMÃ DE ATIVISMO JUDICIAL}

No final da guerra, em 1946, Gustav Radbruch, em razão da experiência proporcionada pelo regime nazista, publicou um polêmico artigo intitulado "Arbitrariedad legal y derecho supralegal" (Radbruch, 1962). Através deste, ele buscava "a superação do positivismo, sob o argumento de que tal matriz teórica é incapaz de tratar da questão da validade por causa da separação que estabelece entre direito e moral"79.

Segundo Trindade e Morais, neste pequeno artigo Radbruch reiterou que:

O direito deve ser entendido como uma ordem ou instituição cujo sentido é servir à justiça, [o artigo] pode ser dividido em duas partes: na primeira, o autor comenta as consequências da legalidade do regime nazista, descrevendo casos que exemplificam esta problemática; na segunda, o autor concentrase na superação do positivismo jurídico - que não consegue explicar a validade das leis -, apresentando sua conhecida fórmula injustiça extrema não é direito - segundo a qual a maior parte do direito produzido pelo regime nazista não mereceria sequer a qualidade de direito -, aplicada pelos tribunais alemães do segundo pós-guerra e adotada, mais recentemente, por Robert Alexy $(1997,2005)^{80}$.

Com essas mudanças, surgiram várias vertentes jusfilosóficas que consideravam que o Direito havia fracassado no período dos regimes totalitários e que, por isso, havia necessidade de "repensar o seu sentido e vínculos com o agir humano, levando em conta a necessidade de se afirmar sua autonomia, sobretudo em relação à política"81.

É nesse contexto que surge a Jurisprudência dos Valores como uma possibilidade para romper com o Positivismo Jurídico e adequar o Direito ao Estado Democrático de Direito:

A Jurisprudência dos Valores propõe uma nova metodologia para o direito, em que a Lei Fundamental alemã aparece como o instituto que deve permear todas as relações jurídicas, sendo que o caso concreto, momento de efetivação do direito, deve ser decidido levando-a em consideração. Para tanto o juiz deve se

\footnotetext{
144.

79 TRINDADE, André Karam; MORAIS, Fausto Santos de. Revista da Faculdade de Direito - UFPR, p.

80 TRINDADE, André Karam; MORAIS, Fausto Santos de. Revista da Faculdade de Direito - UFPR, p. 145 .

81 TRINDADE, André Karam; MORAIS, Fausto Santos de. Revista da Faculdade de Direito - UFPR, p. 145
} 
FONSECA, Lorena; COUTO, Felipe Fróes. Judicialização da Política e ativismo judicial: uma diferenciação necessária. Revista Eletrônica Direito e Política, Programa de Pós-Graduação Stricto Sensu em Ciência Jurídica da UNIVALI, Itajaí, v.13, n.2, 20 quadrimestre de 2018. Disponível em: www.univali.br/direitoepolitica - ISSN 1980-7791

pautar pelos valores estruturados na constituição, posto que estes são a expressão da vontade política da sociedade, o que permite uma decisão que não mais se justifica subjetivamente, mas intersubjetivamente, por ter seus limites previamente estabelecidos de maneira não autoritária ${ }^{82}$.

Trindade e Morais explicam que a jurisprudência de valores foi motivada pela atividade exercida pelo Tribunal Constitucional que retomou o protagonismo judicial na Alemanha, almejando romper com o modelo vigente à época do nazismo e, também, legitimar as decisões tomadas com base na Constituição de 1949, outorgada pelos aliados $^{83}$.

Assim, o Tribunal Constitucional alemão, para embasar suas decisões, passou a elaborar argumentos fundamentados em princípios axiológicos com o objetivo de criar um Direito que ultrapassasse os limites da lei. Para isso, foi preciso "criar mecanismos como, por exemplo, as cláusulas gerais e os enunciados abertos, além de inúmeros princípios que permitiam justificar suas decisões"84.

Acontece que, segundo Tomaz de Oliveira ${ }^{85}$, ao fundamentar a decisão em valores tidos como absolutos e constituídos como princípios norteadores da aplicação do direito, ocorre uma "apropriação subjetiva destes valores por parte do intérprete. Tais valores serão condicionados, em sua explicitação, uma vez que o juiz os interpreta para compreendê-los"86. Assim, se tais valores existem e servem como "ponto de partida para a construção da ordem jurídica, sem que haja a devida institucionalização destes no direito, quando evocados para legitimar uma decisão, esta será sempre calcada em argumentos de valores" ${ }^{\prime \prime 7}$.

\footnotetext{
82 TOMAZ DE OliVeirA, Rafael et al. Anais do X Simpósio Nacional de Direito Constitucional, p. 294.

83 TRINDADE, André Karam; MORAIS, Fausto Santos de. Revista da Faculdade de Direito - UFPR, p. 145

84 TRINDADE, André Karam; MORAIS, Fausto Santos de. Revista da Faculdade de Direito - UFPR, p.

85 TOMAZ DE OLIVEIRA, Rafael et al. Anais do X Simpósio Nacional de Direito Constitucional.

86 TOMAZ DE OLIVEIRA, Rafael et al. Anais do X Simpósio Nacional de Direito Constitucional, p. 295.

87 tOMAZ DE OLIVEIRA, Rafael et al. Anais do X Simpósio Nacional de Direito Constitucional, p. 295.
} 
FONSECA, Lorena; COUTO, Felipe Fróes. Judicialização da Política e ativismo judicial: uma diferenciação necessária. Revista Eletrônica Direito e Política, Programa de Pós-Graduação Stricto Sensu em Ciência Jurídica da UNIVALI, Itajaí, v.13, n.2, 20 quadrimestre de 2018. Disponível em: www.univali.br/direitoepolitica - ISSN 1980-7791

Dessa maneira, esses valores "assumem maior importância que os argumentos de direito, pois no final serão expressão arbitrária do julgador"88, e é como se estivessem acima da política que institui o direito. Por isso, as decisões serão políticas em sentido estrito e não propriamente jurídicas.

O efeito disso foi que, embora o sistema jurídico germânico pertencesse à tradição da civil law, a intensa atividade de seu Tribunal Constitucional Federal (Bundesverfassungsgericht) passou a ser considerada fonte primária da ciência jurídico-constitucional dogmática ${ }^{89}$.

Entretanto, a jurisprudência dos valores passou por dois momentos:

(a) no primeiro, há uma espécie de restauração do jusnaturalismo - fundada em uma ontologia de valores, nos termos propostos por Max Scheler e Nicolai Hartmann, ou em uma filosofia transcendental dos valores, conforme sustentava Gustav Radbruch, adotando a linha neokantista da Escola de Baden -, que afirmava a existência de conteúdo axiológico ou ético-material de natureza suprapositiva como fundamento constitutivo do direito (LARENZ, 1997, pp. 163-182; KAUFAMNN e HASSEMER, 2002, pp. 124-126; CASTANHEIRA NEVES, 2003, pp. 37-42); (b) no segundo, por sua vez, ocorre a construção de mecanismos e procedimentos - e, aqui, surge a ponderação de princípios (Abwägung), mais tarde aperfeiçoada por Alexy capazes de justificar racionalmente as decisões e, assim, afastar a crítica do relativismo, tendo em vista que sua finalidade é, precisamente, minimizar a discricionariedade da atividade jurisdicional (TOMAZ DE OLIVEIRA, 2008, pp. 60-62) ${ }^{90}$

Tal teoria esposada por Alexy (2005) ${ }^{91}$, chamada "Teoria da Argumentação Jurídica" tem o método decisório baseado na premissa não questionada. Segundo essa, a ponderação seria o resultado natural da diferenciação entre regras e princípios. Assim, os princípios teriam um caráter de mandamentos de otimização, "o que implicaria no princípio da proporcionalidade, e vice-versa. Os princípios seriam equiparados a

\footnotetext{
88 TOMAZ DE OLIVEIRA, Rafael et al. Anais do X Simpósio Nacional de Direito Constitucional, p. 295.

89 TRINDADE, André Karam; MORAIS, Fausto Santos de. Revista da Faculdade de Direito - UFPR.

90 TRINDADE, André Karam; MORAIS, Fausto Santos de. Revista da Faculdade de Direito - UFPR, p. 147

${ }^{91}$ ALEXY, Robert. Teoria da argumentação jurídica: a teoria do discurso racional como teoria da fundamentação jurídica. 2. ed. São Paulo: Landy, 2005.
} 
FONSECA, Lorena; COUTO, Felipe Fróes. Judicialização da Política e ativismo judicial: uma diferenciação necessária. Revista Eletrônica Direito e Política, Programa de Pós-Graduação Stricto Sensu em Ciência Jurídica da UNIVALI, Itajaí, v.13, n.2, $2^{\circ}$ quadrimestre de 2018. Disponível em: www.univali.br/direitoepolitica - ISSN 1980-7791

valores, e por isso seriam otimizáveis, e vice-versa"92. Por isso que a ponderação seria inevitável. O problema é que "não se discute por que princípios deveriam ser concebidos dessa maneira, ou por que eles possuiriam esse atributo teleológico de serem realizados na maior medida possível"93, questões que causaram críticas, como se verá a seguir.

O que se pode observar é que quando não há cisão entre teoria e prática, pode ocorrer um "encaixe ao que o intérprete entende que esteja de acordo com o que entende por constituição ou seus fundamentos". Nesse ativismo "busca-se concatenar a decisão do caso concreto pelo que se concebe, subjetivamente e a priori, por Constituição" sem levar em conta a história da Constituição e seus princípios ${ }^{94}$.

Neste contexto, urge pontuar a crítica habermasiana no sentido de que direito venha a ser confundido com bens que podem ter sua aplicação negociada, de acordo com as preferências da autoridade que decide, uma vez que a concepção axiológica das normas não contém universalização suficiente e está enraizada em tais preferencias. ${ }^{95}$ Com isso, há uma "colonização do mundo da vida pelo poder judiciário, com a expansão da racionalidade instrumental, desalojando a racionalidade comunicativa"96 o que pode gerar uma crise de legitimidade do direito.

Trindade e Morais indicam que para Habermas no "Estado democrático de direito, o papel a ser desempenhado pelos tribunais constitucionais deve ficar restrito a uma compreensão procedimental da Constituição"97. Assim, na proposta de Habermas, os tribunais devem se limitar a garantir o processo de criação democrática do direito e

\footnotetext{
92 PEDRON, Flávio Barbosa Quinaud. Comentários sobre as interpretações de Alexy e Dworkin. Revista CEJ, Brasília, vol. 9. n. 30. p. 70-80, jul.-set. 2005, p. 87.

93 PEDRON, Flávio Barbosa Quinaud. Revista CEJ, p. 87.

94 TOMAZ DE OLIVEIRA, Rafael et al. Anais do X Simpósio Nacional de Direito Constitucional, p. 296.

95 PEDRON, Flávio Barbosa Quinaud. Revista CEJ, p. 75-76.

96 PEDRON, Flávio Barbosa Quinaud. Revista CEJ, p. 75-76.

97 TRINDADE, André Karam; MORAIS, Fausto Santos de. Revista da Faculdade de Direito - UFPR, p. 149.
} 
FONSECA, Lorena; COUTO, Felipe Fróes. Judicialização da Política e ativismo judicial: uma diferenciação necessária. Revista Eletrônica Direito e Política, Programa de Pós-Graduação Stricto Sensu em Ciência Jurídica da UNIVALI, Itajaí, v.13, n.2, $2^{\circ}$ quadrimestre de 2018. Disponível em: www.univali.br/direitoepolitica - ISSN 1980-7791

não atuarem como guardiões de uma suposta ordem suprapositiva de valores substantivos $^{98}$.

Apesar das críticas de que o Tribunal Constitucional alemão compromete o ideal democrático, ele não diminuiu sua atuação e suas decisões, sobretudo aquelas sobre os direitos fundamentais, constituíram objeto dos mais importantes estudos jurídicos em todo o mundo. Ao longo dos anos de atividade, o Tribunal constitucional alemão vem mantendo a postura inaugurada pela jurisprudência de valores e exportando para o mundo, assim, a discricionariedade judicial, através da técnica da ponderação, sob a justificativa teórica de uma maior racionalidade do discurso jurídico ${ }^{99}$.

Diante dessa breve intelecção, podemos afirmar que no ativismo alemão a melhor interpretação para a Constituição precede a sua aplicação, mostrando-se como um processo metódico que busca legitimar suas decisões através de procedimentos como a ponderação. De outra monta, o ativismo norte-americano concentra-se no problema da aplicação da Constituição, "que acaba por se colmatar à tradição do 'common law' em que os juízes buscam, no caso concreto, dar a melhor interpretação para a Constituição"100. Assim, o direito seria aquilo que o tribunal diz por meio da sua criação jurisprudencial.

\section{CONSIDERAÇÕES FINAIS}

Neste trabalho, buscou-se expor como se deu o crescimento da atividade jurisdicional e foi feita a diferenciação entre os fenômenos do ativismo judicial e da judicialização da política. O primeiro, inserido na Teoria do Direito, trata do ato de vontade, da postura interpretativa nas decisões proativas e eminentemente políticas. Nestas são utilizados critérios não jurídicos que extrapolam os limites de atuação do juiz/tribunal. Já o segundo fenômeno é fruto de um contexto social e político em que há transferência para o Judiciário de questões que não são exclusivamente jurídicas e que

\footnotetext{
98 TRINDADE, André Karam; MORAIS, Fausto Santos de. Revista da Faculdade de Direito - UFPR, p. 149.

99 TRINDADE, André Karam; MORAIS, Fausto Santos de. Revista da Faculdade de Direito - UFPR, p. 150-151. 296.

100 TOMAZ DE OLIVEIRA, Rafael et al. Anais do X Simpósio Nacional de Direito Constitucional, p.
} 
FONSECA, Lorena; COUTO, Felipe Fróes. Judicialização da Política e ativismo judicial: uma diferenciação necessária. Revista Eletrônica Direito e Política, Programa de Pós-Graduação Stricto Sensu em Ciência Jurídica da UNIVALI, Itajaí, v.13, n.2, $2^{\circ}$ quadrimestre de 2018. Disponível em: www.univali.br/direitoepolitica - ISSN 1980-7791

repercutem em questões sociais e políticas da sociedade. Logo, judicialização é um fato, ativismo é atitude.

Também apontamos as causas da judicialização como sendo: constitucionalismo do segundo pós-guerra, noção de "constituição dirigente", aumento da litigiosidade e demandas por justiça. Já para esclarecer a origem do ativismo judicial, como ato de vontade do julgador, nos reportamos à "Teoria Pura do Direito" de Hans Kelsen e às explanações de Antoine Garapon em "O guardador de promessas".

Com isso, foi possível indicar que o ativismo judicial aparece como um problema criado exclusivamente pelo âmbito jurídico, diferente da judicialização que está condicionada a acontecimentos externos ao Direito. Além disso, esclarecemos que o problema do ativismo é de cunho interpretativo, sendo necessário averiguar se a intervenção do judiciário ocorre dentro dos limites constitucionais.

Explanamos também neste trabalho sobre o ativismo pioneiro dos EUA, responsável por criar um controle de constitucionalidade (judicial review), que sequer era previsto textualmente na Constituição e sua influência na tribunalização da política. Indicamos que tal ativismo advindo da jurisprudência, bem como o desenvolvimento de técnicas interpretativas, ocorreu de forma gradativa. Além da experiência norte-americana, apontamos a influência da Jurisprudência de Valores alemã que buscava argumentos fundamentados em princípios axiológicos com o objetivo de criar um Direito que ultrapassasse os limites da lei. O Tribunal da Alemanha utilizava essa Jurisprudência e, por meio da técnica de ponderação, exportou para o mundo a discricionariedade judicial.

\section{REFERÊNCIAS DAS FONTES CITADAS}

ALEXY, Robert. Teoria da argumentação jurídica: a teoria do discurso racional como teoria da fundamentação jurídica. 2. ed. São Paulo: Landy, 2005.

BARROSO, Luís Roberto. Judicialização, ativismo judicial e legitimidade democrática. [Syn]Thesis, Rio de Janeiro, v. 5, n. 1, p. 23-32, 2012.

BRASIL, Supremo Tribunal Federal. Ação Direta de Constitucionalidade 12. Relator: Min. Carlos Britto. Tribunal Pleno, Julgado em: 20/08/2008, DJ: 17-12-2009, Publicado: 18-12-2009. Disponível em: <http://www.stf.jus.br/portal/processo/verProcessoAndamento.asp>. Acesso em: $10 / 03 / 2015$ às $9 h$. 
FONSECA, Lorena; COUTO, Felipe Fróes. Judicialização da Política e ativismo judicial: uma diferenciação necessária. Revista Eletrônica Direito e Política, Programa de Pós-Graduação Stricto Sensu em Ciência Jurídica da UNIVALI, Itajaí, v.13, n.2, $2^{\circ}$ quadrimestre de 2018. Disponível em: www.univali.br/direitoepolitica - ISSN 1980-7791

Supremo Tribunal Federal. Ação Direta de Inconstitucionalidade 3510.

Relator: Min. Ayres Britto. Tribunal Pleno, julgado em: 29/05/2008, DJ: 27-05-2010, Publicado: 28-05-2010. Disponível em: <http://www.stf.jus.br/arquivo/informativo/documento/informativo508.htm.>. Acesso em: 10/03/2015 às $12 \mathrm{~h}$.

CADEMARTORI, Daniela Mesquista Leutchuk de. O diálogo democrático: Alain Touraine, Noberto Bobbio e Robert Dahl. Curitiba: Juruá, 2006.

CANOTILHO, José Joaquim Gomes. Constituição dirigente e vinculação do legislador: contributo para a compreensão das normas constitucionais programáticas. 2. ed. Coimbra: Coimbra Editora, 2001.

CANOTILHO, José Joaquim Gomes. Direito Constitucional e teoria da Constituição. 7 ed. Coimbra: Almedina, 2003.

DWORKIN, Ronald. Levando os direitos a sério. São Paulo: Martins Fontes, 2002.

FERRAJOLI, Luigi. Sobre los derechos fundamentales. Tradução de Miguel Carbonell. In: CARBONELL, Miguel (Org.). Teoría del neoconstitucionalismo: ensayos escogidos. Madrid: Trotta, 2007.

GARAPON, Antoine. O guardador de promessas: justiça e democracia. Tradução de Francisco Aragão. Lisboa: Instituto Piaget, 1998.

HABERMAS, Jürgen. Teoría de la acción comunicativa. 2. ed. Madrid: Taurus, 2001.

HESSE, Konrad. A Força Normativa da Constituição. Trad. Gilmar Ferreira Mendes. Porto Alegre: Safe, 1991.

KELSEN, Hans. Teoria pura do direito. Tradução de João Baptista Machado. São Paulo: Martins Fontes, 1999.

LAKATOS, Eva Maria; MARCONI, Marina de Andrade. Metodologia científica. São Paulo: Atlas, 2000.

LEITE, Roberto Basilone. Déficit político do poder judiciário brasileiro: A falta de efetividade no desempenho de suas funções institucionais e o ativismo judicial como interferência indevida em área de atuação própria do poder político. Tese (Doutorado em Direito) - Universidade Federal de Santa Catarina. Florianópolis, 2011.

LEVY, Leonard W. Marbury v. Madison. In: KARST, Kenneth L; MAHONEY, Dennis J. (Orgs.). Judicial Power and the Constitution: selections from the Encyclopedia of the American Constitution. New York: Macmillan, 1990.

MELO, Manuel Palacios Cunha. A Suprema Corte dos EUA e a judicialização da política: notas sobre um itinerário difícil. In: VIANNA, Luiz Werneck (org.) A democracia e os três poderes no Brasil, 2002.

MICHELMAN, Frank. La democrazia e il potere giudiziario: il dilemma costituzionale e il giudice Brennan. Bari: Dedalo, 2004. 
FONSECA, Lorena; COUTO, Felipe Fróes. Judicialização da Política e ativismo judicial: uma diferenciação necessária. Revista Eletrônica Direito e Política, Programa de Pós-Graduação Stricto Sensu em Ciência Jurídica da UNIVALI, Itajaí, v.13, n.2, $2^{\circ}$ quadrimestre de 2018. Disponível em: www.univali.br/direitoepolitica - ISSN 1980-7791

PEDRON, Flávio Barbosa Quinaud. Comentários sobre as interpretações de Alexy e Dworkin. Revista CEJ. Brasília, vol. 9. n. 30. p. 70-80, jul.-set. 2005.

RIBEIRO, Diógenes V. Hassan. Judicialização e desjudicialização, entre a deficiência do legislativo e a insuficiência do judiciário. Revista de Informação Legislativa, Ano 50, Número 199, jul./set. 2013.

SCHWARTZ, Bernard. The Warren Court: a retrospective. Oxford: Oxford University Press, 1996.

Bernard. A book of legal lists: the best and worst in american law. Oxford: Oxford University Press, 1997.

SILVA, José Afonso da. Aplicabilidade das Normas Constitucionais. 3 ed, São Paulo, Malheiros, 1998.

STRECK, Lenio Luiz. Verdade e consenso. Constituição hermenêutica e teorias discursivas. 4. ed. São Paulo: Saraiva, 2011.

SURGIK, Aloisio; WACHELESKI, Marcelo Paulo. O Poder Judiciário e as decisões políticas: uma crítica a partir da teoria procedimentalista. Revista Eletrônica Direito e Política, Programa de Pós Graduação Stricto Sensu em Ciência Jurídica da UNIVALI, Itajaí, v. 9, n. 3, 30 quadrimestre de 2014.

TASSINARI, Clarissa. Ativismo judicial: uma análise da atuação do judiciário nas experiências brasileira e norte-americana. Dissertação (Mestrado em Direito) Universidade do Vale do Rio dos Sinos. São Leopoldo, 2012.

TATE, C. Neal; VALLINDER, Torbjörn (Eds.). The global expansion of judicial power. New York: New York University Press, 1995.

TOMAZ DE OLIVEIRA, Rafael et al. A jurisdição constitucional entre a judicialização e o ativismo: percursos para uma necessária diferenciação. Anais do X Simpósio Nacional de Direito Constitucional, 2012.

Consultor
' Rafael. Ficha Limpa intensificou a judicialização da política. Revista
Ju de outubro de 2012. Disponível em: <http://www.conjur.com.br/2012-out-06/diario-classe-ficha-limpa-intensificoujudicializacao-politica >. Acesso em 18/02/2015 às $12 \mathrm{~h}$.

TRINDADE, André Karam; MORAIS, Fausto Santos de. Ativismo judicial: As experiências norte-americana, alemã e brasileira. Revista da Faculdade de Direito - UFPR, Curitiba, n. 47, p. 137-164, 2011.

VALLE, Vanice Regina Lírio do (Org.). Ativismo jurisdicional e o Supremo Tribunal Federal: laboratório de Análise Jurisprudencial do STF. Curitiba: Juruá, 2009.

WOLFE, Christopher. The rise of modern judicial review: From constitutional interpretation to judge-made law. Boston: Littlefield Adams Quality Paperbacks, 1994.

Sites: 
FONSECA, Lorena; COUTO, Felipe Fróes. Judicialização da Política e ativismo judicial: uma diferenciação necessária. Revista Eletrônica Direito e Política, Programa de Pós-Graduação Stricto Sensu em Ciência Jurídica da UNIVALI, Itajaí, v.13, n.2, $2^{\circ}$ quadrimestre de 2018. Disponível em: www.univali.br/direitoepolitica - ISSN 1980-7791

<http://g1.globo.com/politica/noticia/2011/04/vaga-de-deputado-licenciado-e-desuplente-da-coligacao-decide-stf.html>. Acesso em 10/02/2015.

<http://noticias.terra.com.br/brasil/aborto-de-anencefalos-nao-e-mais-crimedecide-stf,517bdc840f0da310VgnCLD200000bbcceb0aRCRD.html>. Acesso em $11 / 02 / 2015$.

<http://www.gazetadopovo.com.br/vida-e-cidadania/toque-de-recolher-chega-aoparana-bnlOwlikm5zifcqgdf4e0tgzy>. Acesso em: 06/05/ 2015.

Recebido em: 01/06/2016

Aprovado em: 02/07/2018 